\title{
POTENCY AND USE OF CHIA MUCILAGE COATING CONTAINING PROPOLIS LIQUID EXTRACT FOR IMPROVES SHELF-LIFE OF SEA BASS FILLETS
}

\author{
Mehmet Zülfü Coban ${ }^{1 凶}$, Ozlem Emir Coban² \\ ${ }^{1}$ Keban Vocational Schools, Firat University, Keban, Turkey \\ ${ }^{2}$ Department of Fish Processing Technology, Firat University, Elazig, Turkey
}

\begin{abstract}
Background. In this study the effects of the use of chia mucilage - CM coating in combination with propolis liquid extract - PLE on the physico-chemical (total volatile basic nitrogen - TVB-N, peroxide value - PV, thiobarbituric acid - TBA) and bacteriological (total viable count - TVC, psychrophilic bacteria count PBC) quality properties of sea bass fillets during storage at $2{ }^{\circ} \mathrm{C}$, as well as its potency, were investigated. Materials and methods. The fillets were randomly separated into four lots and subjected to the following treatments by dipping: chia mucilage $-\mathrm{CM}$, chia mucilage $+0.1 \%$ PLE, chia mucilage $+0.3 \%$ PLE and control (uncoated), then stored at $2^{\circ} \mathrm{C}$.

Results. The results showed that the chia musilage coating containing PLE was effective on TVC and PCA. While the shelf life of the control group was 8 days, the CM + 0.3\% PLE group was 20 days.

Conclusion. According to these results, it can be said that chia mucilage coating preserves the shelf life and quality of chilled seafood and can be used safely as a coating material.
\end{abstract}

Keywords: edible coating, chia mucilage, propolis, sea bass, quality, shelf-life

\section{INTRODUCTION}

Edible coatings are a thin layer of material that can be consumed as part of a food product and are biodegradable to act as a selective barrier to gas transport. Fresh fish are extremely sensitive to spoilage. Degradation is mainly caused by biological reactions such as oxidation of lipids, protein decomposition, which is mediated by endogenous or microbial enzymes. These activities shorten the shelf life of fish and other seafood. Edible coatings have long been used to delay dehydration of food products, improve textural quality, help preserve volatile flavour compounds, and reduce microbial growth. Edible films and coatings are classified as proteins, polysaccharides or lipids (Azeredo et al., 2012; Hosseini et al., 2016).

Extracts are natural products used in food preservation and for their antiseptic, antioxidant, digestive stimulant, antimicrobial and enzymatic effects. Most plant extracts are included in the GRAS list (Kabara, 1991), one of which is propolis. Propolis has antifungal, antibacterial, antioxidant and antiviral properties. It is also widely used in folk medicine. Propolis contains benzoic acid, cinnamic acid, phenols, ketophenols, hydroquinone, coumarins and naphthalene (Galeotti et al., 2018). 
Chia seeds (Salvia hispanica) have become increasingly important worldwide due to their nutritious and functional properties. It has been observed that chia seeds kept in water form a gel of a slightly sticky and transparent gum. Chia seed mucilage contains high molecular weight xylol, glucose and methyl glucuronic acid. Chia mucilage has been described by the food and agriculture organization as a potential source of polysaccharides due to its outstanding gelling properties in water, even at very low concentrations (Dick et al., 2015; Munoz et al., 2012). Chia mucilage is a foam stabilizer, and the suspension resulting from it can be used as an emulsifier, adhesive or binder in the food industry (Salgado-Cruz et al., 2013). According to the research, there is no literature about the application of chia seed mucilage in seafood.

In the present study the use and potency of chia musilage with propolis liquid extract as an edible coating for the protection of sea bass (Dicentrarchus labrax, Linnaeus 1758) fillets stored for 20 days at $2^{\circ} \mathrm{C}$ were investigated.

\section{MATERIALS AND METHODS}

Sea bass (Dicentrarchus labrax) was purchased from a fish market (Elazığ / Turkey). In this study, a total of 20 sea bass samples with an approximate weight of $350 \pm 20 \mathrm{~g}$ were used. Firstly, the heads and viscera were immediately removed and skinless fillets were prepared. The chia seeds used in the preparation of coatings were obtained from local markets and the propolis liquid extract was purchased from a commercial company (Organic pavilion).

\section{Preparation of coating solution}

Chia mucilage was obtained using the hydration process (Dick et al., 2015). The chia seeds were mixed with distilled water at a ratio of 1:20 with a magnetic stirrer (Hot \& Stirrer-Hill, MS300HS) for 2 hours at $25^{\circ} \mathrm{C}$. Then, glycerol $(1 \%)$ was added as the plasticizer and mixed again at $25^{\circ} \mathrm{C}$ for 15 minutes. The mixture was then centrifuged (Core NF 800R) to remove insoluble particles and then filtered to remove seeds from the mucilage.

For the addition of the propolis liquid extract to the chia mucilage, $0.1 \%$ and $0.3 \%$ PLE were dissolved in Tween $20(0.5 \% \mathrm{v} / \mathrm{v})$ and homogenized with a homogenizer (Wise Stir DAIHAN Scientific HS$30 \mathrm{E})$ at $20000 \mathrm{rpm}$ for 1 minute and then added to the prepared chia mucilage.

The sea bass fillets were washed with cold sterile water before coating and removed from the water by standing in a sterile incubator $\left(4^{\circ} \mathrm{C}\right.$ and $\left.50 \% \mathrm{RH}\right)$ for 15 minutes.

\section{Coating process and storage}

The fillets were divided into three groups and immersed in the coating solutions (pure chia mucilage (CM), $0.1 \%$ PLE added CM and 0.3\% PLE added $\mathrm{CM}$ ) at $4^{\circ} \mathrm{C}$ for 3 times 2-minute intervals (with a fillet/solution ratio of 1:3). After immersion, the fillets were removed and dried for 60 minutes with airflow $\left(4{ }^{\circ} \mathrm{C}\right.$ and $\left.50 \% \mathrm{RH}\right)$ in a sterile incubator. Subsequently, each sample was individually placed in an airtight sterile polyethylene bag and stored at $2{ }^{\circ} \mathrm{C}$ for up to 20 days. Random samples from each group were analysed on days $0,4,8,12,16$ and 20 . The study was conducted with two replications.

\section{Physicochemical analysis}

Total volatile basic nitrogen - TVB-N analysis was performed according to the micro-diffusion method reported by Goulas and Kontominas (2005). Values are given in $\mathrm{mg} \mathrm{N} / 100 \mathrm{~g}$. Thiobarbituric acid - TBA analysis of the fillets was determined by the spectrophotometric method specified by Kirk and Sawyer (1991). The peroxide value of the fillets was determined according to the American Oil Chemists' Society (AOCS, 1985). Peroxide value - PV was calculated using the following equation:

$$
\mathrm{PV}, \mathrm{meq} / \mathrm{kg}=(V-B \times \mathrm{Nf} / W) \times 1000
$$

where:

$\mathrm{V}$ and $\mathrm{B}$ - the volume of the sodium thiosulfate, blind and used in the titration of the sample, $\mathrm{mL}$

$\mathrm{Nf}$ - the concentration of sodium thiosulfate,

$W$ - the sample weight, $g$.

\section{Bacteriological analyses}

Plate Count Agar was used for the total viable count (TVC) and psychrophilic bacteria count (PBC) (Halkman, 2005). The TVC and PBC were performed using the pour plate method. The samples was incubated at 
$35^{\circ} \mathrm{C}$ for $48 \mathrm{~h}$, or at $7^{\circ} \mathrm{C}$ for 10 days. The results were expressed as $\log \mathrm{cfu} / \mathrm{g}$.

\section{STATISTICAL ANALYSIS}

Data from the physicochemical and bacteriological parameters were subjected to one-way analysis of variance (one-way ANOVA) using IBM SPSS ${ }^{\circledR} 26$ (SPSS Inc., Chicago, IL, USA) software. The least squares difference (LSD) method was used to compare the means $(p<0.05)$.

\section{RESULTS AND DISCUSSION}

Changes in the TVB-N values of all groups during storage are given in Figure 1. In the control group, the TVB-N value of the fillets (Cont, CM, 0.1\% PLE + CM, $0.3 \%$ PLE + CM) on day 0 was $18.12 \mathrm{mg} \mathrm{N} / 100 \mathrm{~g}$, $18.00 \mathrm{mg} \mathrm{N} / 100 \mathrm{~g}, 18.20 \mathrm{mg} \mathrm{N} / 100 \mathrm{~g}$, and $18.10 \mathrm{mg}$ $\mathrm{N} / 100 \mathrm{~g}$, respectively. The TVB-N value of the control group and coated groups significantly increased $(p<0.05)$ with the progress of the storage time. But, the TVB-N value was significantly lower in the chia mucilage (CM) coatings with added propolis liquid extract (PLE), than in the control group $(p<0.05)$. These results in particular demonstrated that $0.3 \%$ PLE added to the chia mucilage coating could inhibit TVB-N values below the maximum acceptability limit $(35 \mathrm{mg}$ N/100 g) (Varlık et al., 1993). Can and Emir Çoban (2012) reported that the TVB-N increase of rainbow trout coated with Zein was slower during the storage period $(p<0.05)$. Kawiji et al. (2014) found that the

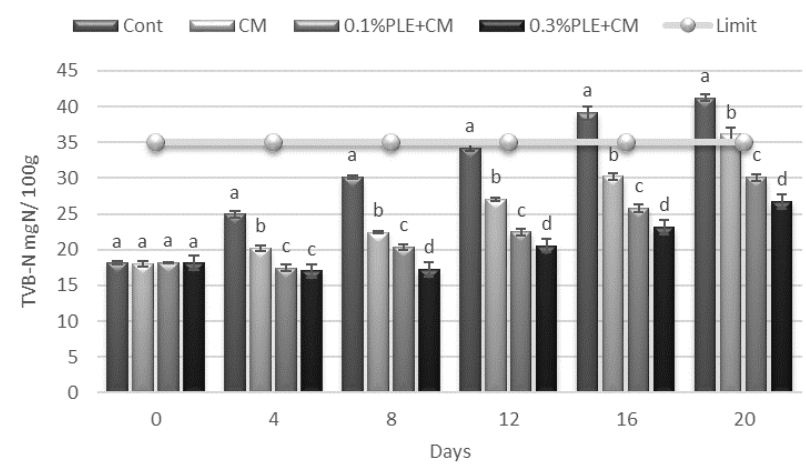

Fig. 1. Changes in total volatile bases of sea bass fillets at $2^{\circ} \mathrm{C}, \mathrm{mg}$ TVB-N/100 g increase in TVB-N values of the coating enriched with Curcuma xanthorrhiza was less than that of the control group and remained below the consumable limit value (35 mg N/100 g) during storage. According to Jonaidi et al. (2018), the TVB-N value for the control group of chicken fillets was higher than chitosan-propolis treatments $(p<0.05)$. Nessianpour et al. (2019) observed that the TVB-N values of $S$. tumbil fillets treated with gelatın-propolis combinations were lower than those of the control group.

Thiobarbituric acid - TBA is an index as used index for assessing the degree of lipid oxidation in seafood and other meat products (Alparslan et al., 2014). The change in TBA values of the sea bass fillets is shown in Figure 2. Thiobarbituric acid - TBA values of all the groups increased at different rates during storage, but the chia mucilage coated group contain-

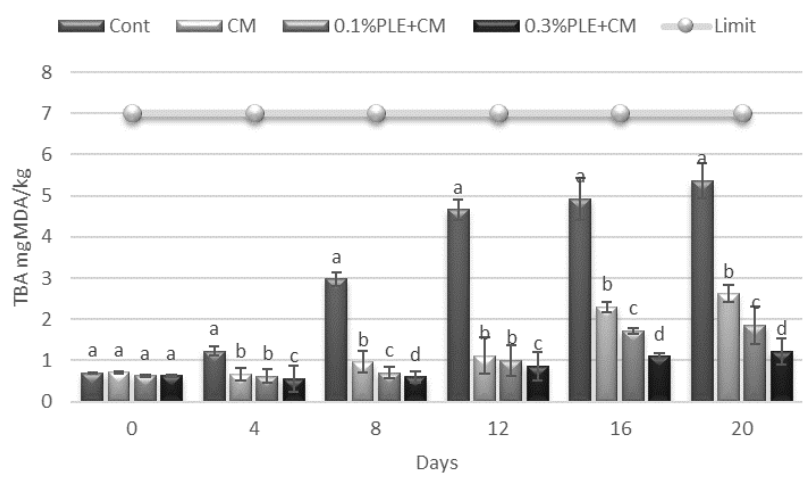

Fig. 2. Changes in $\mathrm{TBA}$ of sea bass fillets at $2^{\circ} \mathrm{C}, \mathrm{mg} \mathrm{MDA} / \mathrm{kg}$

ing propolis liquid extract showed less increase during storage compared to the other groups $(p<0.05)$. Thiobarbituric acid - TBA values of the control, CM, 0.1\% PLE + CM and $0.3 \%$ PLE + CM were determined as between $0.63-0.71 \mathrm{mg} \mathrm{MDA} / \mathrm{kg}$ on day 0 . With respect to the results, a significant difference was found between the chia mucilage coated samples and control samples after the $4^{\text {th }}$ day $(p<0.05)$. This result may be due to the barrier properties of the coatings and its ability to reduce lipid oxidation (Fadıloğlu and Emir Çoban, 2018; Ojagh et al., 2010; Qiu et al., 2014). In addition, a significant difference was found between the groups with PLE and the other groups $(p<0.05)$. 
Coban, M. Z., Coban, O. E. (2020). Potency and use of chia mucilage coating containing propolis liquid extract for improves shelf-life of sea bass fillets. Acta Sci. Pol. Technol. Aliment., 19(3), 255-260. http://dx.doi.org/10.17306/J.AFS.2020.0843

Similar studies were also conducted by Payandan et al. (2017), Reis et al. (2017), Nessianpour et al. (2019) and Çoban et al. (2018), who reported that the TBA value slowed down in the presence of propolis extract. Accordingly, coatings with propolis liquid extract can be said to be more effective than coatings alone, which can be explained by the presence of bioactive substances contained in the propolis liquid extract and their synergistic interactions with lipid oxidation.

Peroxide value is the primary oxidation product used in the determination of oxidation in oils. At the beginning, peroxide values for the control, $\mathrm{CM}, 0.1 \%$ $\mathrm{PLE}+\mathrm{CM}$ and $0.3 \% \mathrm{PLE}+\mathrm{CM}$ groups were $5.01 \mathrm{meq}$ $\mathrm{O}_{2} / \mathrm{kg}, 5 \mathrm{meq} \mathrm{O}_{2} / \mathrm{kg}$ and $4.87 \mathrm{meq} \mathrm{O}_{2} / \mathrm{kg}, 4.12 \mathrm{meq} \mathrm{O}_{2} / \mathrm{kg}$ respectively (Fig. 3). The highest rise of PV was displayed for the uncoated (control) group. The peroxide value of all the groups increased during storage at $2^{\circ} \mathrm{C}$. The $\mathrm{PV}$ of the coated groups remained relatively low $(p<0.05)$. These conclusions might be due to the strong antioxidant activity of the chia mucilage coating and propolis liquid extract prohibiting the hydrolysis of the unsaturated fatty acids of seabass fillets. Varlık et al. (1993) classified the peroxide values as $2 \mathrm{meq} \mathrm{O}_{2} / \mathrm{kg}$ "very good", 5 meq $\mathrm{O}_{2} / \mathrm{kg}$ "good" and 8-10 meq $\mathrm{O}_{2} / \mathrm{kg}$ "acceptable limit". The coating groups with added propolis liquid extract were below the acceptable limit even on the 20th day $(p<0.05)$. Similar results were obtained by Alparslan et al. (2014) for Oncorhynchus mykiss coated with bay leaf chitosan, Zarei et al. (2015) for Silver carp coated with chitosan supplemented with oregano and pomegranate peel extract, and Fadıloğlu

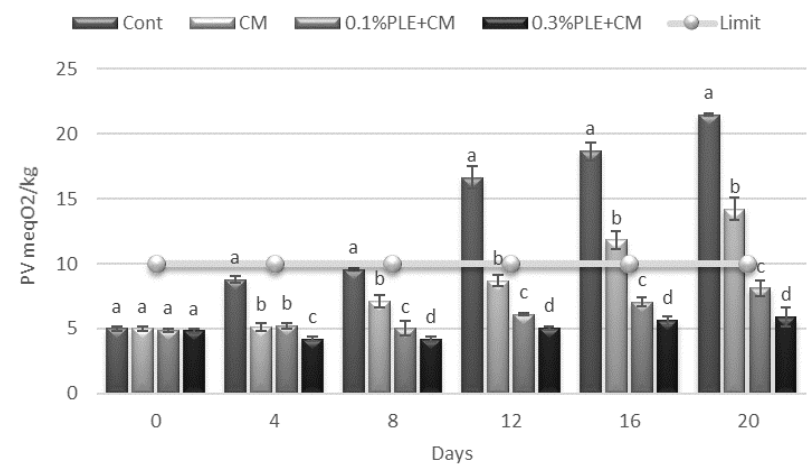

Fig. 3. Changes in peroxide value of sea bass fillets at $2^{\circ} \mathrm{C}$, meq $\mathrm{O}_{2} / \mathrm{kg} \mathrm{PV}$

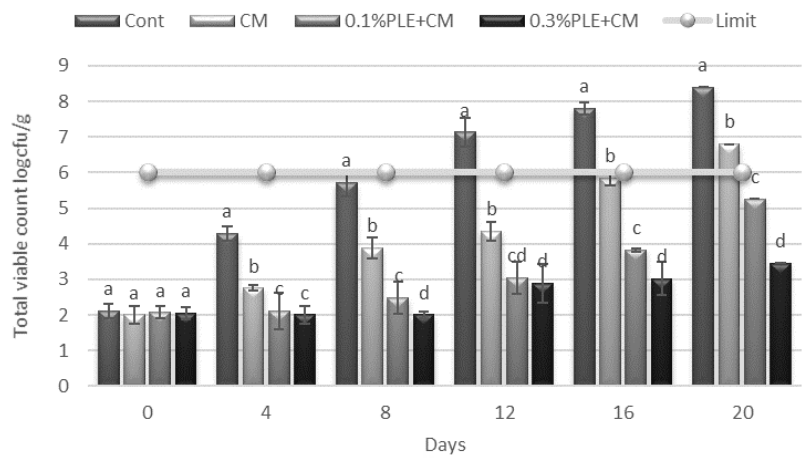

Fig. 4. Changes in TVC of sea bass fillets at $2^{\circ} \mathrm{C}, \log \mathrm{cfu} / \mathrm{g}$

and Emir Çoban (2018) for Oncorhynchus mykiss coated with chitosan enriched with sumac extracts.

Microbial activity is a limiting factor for fish and fish product quality (Ouattara et al., 1997). The activity of the control and coated groups on the total viable count (TVC) during storage at $2{ }^{\circ} \mathrm{C}$ for 20 days is demonstrated in Figure 4. The initial TVC of CM, 0.1\% PLE + CM and 0.3\% PLE + CM groups was $2.12 \mathrm{log}$ $\mathrm{cfu} / \mathrm{g}, 2.00 \log \mathrm{cfu} / \mathrm{g}, 2.07 \mathrm{log} \mathrm{cfu} / \mathrm{g}$ and $2.05 \mathrm{log} \mathrm{cfu} / \mathrm{g}$, respectively. No difference was observed between the control group and the treatments at day $0(p>0.05)$. Throughout storage, the TVC results were significantly lower in the chia mucilage coatings with added propolis liquid extract, than in the other groups $(p<0.05)$. The control group exceeded $6 \mathrm{log} \mathrm{cfu} / \mathrm{g}$ (ICMSF, 1986) on the $12^{\text {th }}$ day. According to these results, it can be said that chia mucilage coating and propolis liquid extract application has an inhibitory effect on the total mesophilic aerobic bacteria. The mechanism of antimicrobial action of phenolic compounds found in plant extracts and oils such as propolis, is associated with the sensitization of the phospholipid membrane surrounding the bacterial nucleus. This phenomenon increases the permeability of the membrane and leads to leakage of intracellular compounds, such as vital enzymes, outside the cell (Ouattara et al., 1997; Payandan et al., 2017). Different natural preservatives applied with different coating materials have shown similar effects to the present study. Ojagh et al. (2010) reported that the TVC of chitosan coated rainbow trout fillets with cinnamon oil was lower than the control group during storage. Özyurt et al. (2015) reported that TVC increased faster in the control group which 


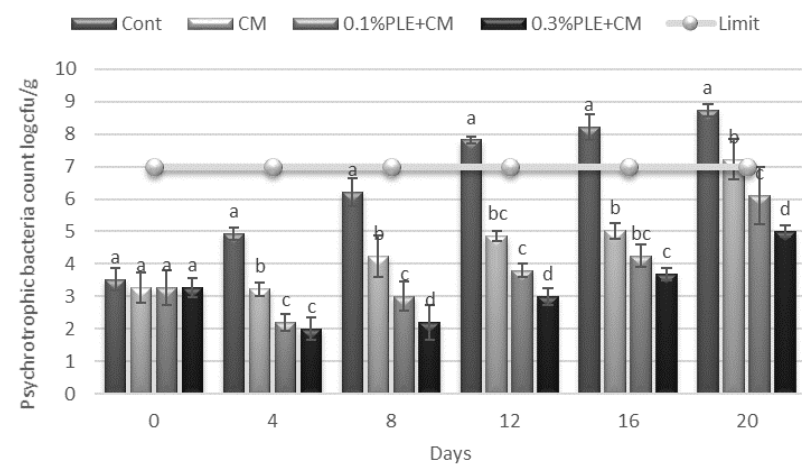

Fig. 5. Changes in $\mathrm{PBC}$ of sea bass fillets at $2^{\circ} \mathrm{C}, \log \mathrm{cfu} / \mathrm{g}$

was not coated with a fish protein based edible film. In their studies on rainbow trout, Fadıloğlu and Çoban (2018) found that chitosan coating enriched with sumac extract inhibited the growth of TVC.

The changes in psychrotrophic bacteria count (PBC) of the sea bass fillets during storage at $2^{\circ} \mathrm{C}$ are shown in Figure 5. psychrophilic bacteria count - PBC increased in all groups during storage. The highest increase was detected in the control group $(p<0.05)$. At the end of the storage period, PB counts were determined as $8.74 \mathrm{log} \mathrm{cfu} / \mathrm{g}, 7.22 \mathrm{log} \mathrm{cfu} / \mathrm{g}, 6.11 \mathrm{log}$ $\mathrm{cfu} / \mathrm{g}, 5.01 \mathrm{log} \mathrm{cfu} / \mathrm{g}$, for the control, CM, 0.1\% PLE + $\mathrm{CM}$ and $0.3 \% \mathrm{PLE}+\mathrm{CM}$, respectively. The obtained results for CM + PLE groups were considerably lower than the accepted limit of $7 \log \mathrm{cfu} / \mathrm{g}$ (ICMSF, 1986). Propolis liquid extract treatments inhibited the growth of psychrotrophic bacteria count, a fact which has been confirmed by many researchers, such as Jafari et al. (2017), Fadıloğlu and Emir Çoban (2018) and Yazgan et al. (2020). According to these findings, it was concluded that chia mucilage coating, like other materials used to coat fish and fish products, has a significant effect on decreasing the psychrophilic bacteria count.

\section{CONCLUSION}

In this study, it was determined that chia mucilage can be used as an alternative coating material which can be used in the edible film and coating industry. In particular, chia mucilage coating enriched with PLE has been found to successfully inhibit lipid oxidation and microbial growth in the product. The shelf life of the sea bass fillets coated with chia with added propolis liquid extract could be preserved throughout storage (20 days), while the shelf life of the control group was 8 days. Therefore, the chia mucilage coating used with propolis liquid extract can be recommended as a safe and alternative preservative for processing fish during cold storage.

\section{REFERENCES}

Alparslan, Y., Baygar, T., Baygar, T., Hasanhocaoglu, H., Metin, C. (2014). Effects of gelatin-based edible films enriched with laurel essential oil on the quality of rainbow trout (Oncorhynchus mykiss) fillets during refrigerated storage. Food Technol. Biotechnol., 52(3), 325-333.

AOCS (1985). The official and tentative methods of the American Oil Chemist's Society (3rd ed). Champaign, Illinoi: American Oil Chemist's Society.

Azeredo, H. M. C., Miranda, K. W. E., Ribeiro, H. L., Rosa, M. F., Nascimento, D. M. (2012). Nanoreinforced alginate-acerola puree coatings on acerola fruits. J. Food Eng., 113, 505-510.

Can, Ö. P., Emir Çoban, Ö. (2012). Comparison of the effects of vacuum packaging and zein coating on the quality criteria of fish fillets. J. Biol. Res., 5(1), 87-91.

Çoban, Ö. E., Fadıloğlu, E. E., Çoban, M. Z. (2018). Investigation of some quality characteristics of smoked common carp (Cyprinus carpio) sausages supplemented with propolis extract. Ecol. Life Sci., 13(4), 197-203.

Dick, M., Costa,T. M. H., Gomaa, A., Subirade, M., Rios, A. de O., Flôres, S. H. (2015). Edible film production from chia seed mucilage: Effect of glycerolconcentration on its physicochemical and mechanical properties. Carbohydr. Polym., 130, 198-205.

Fadıloğlu, E. E., Emir Çoban, Ö. (2018). Effects of chitosan edible coatings enriched with sumac on the quality and the shelf-life of rainbow trout (Oncorhynchus mykiss, Walbaum, 1792) fillets. J. Food Safety, 38(6) e12545.

Galeotti, F., Maccari, F., Fachini, A., Volp, N. (2018). Chemical composition and antioxidant activity of propolis prepared in different forms and in different solvents useful for finished products. Foods, 7, 41.

Goulas, A. E., Kontominas, M. G. (2005). Effect of salting and smoking-method on the keeping quality of chub mackerel (Scomber japonicus): Biochemical and sensory attributes. Food Chem., 93(3), 511-520.

Halkman, A. K. (2005). Merck food microbiology applications. Ankara: Başak Matbaacıllk.

Hosseini, S. F., Rezaei, M., Zandi, M., Ghavi, F. F. (2016). Effect of fish gelatin coating enriched with oregano 
Coban, M. Z., Coban, O. E. (2020). Potency and use of chia mucilage coating containing propolis liquid extract for improves shelf-life of sea bass fillets. Acta Sci. Pol. Technol. Aliment., 19(3), 255-260. http://dx.doi.org/10.17306/J.AFS.2020.0843

essential oil on the quality of refrigerated rainbow trout fillet. J. Aquat. Food Prod. Technol., 25(6), 835-842.

ICMSF (1986). International Commisson on Microbiological Specifications for Foods. Microorganisms in foods 2. Sampling for microbiological analysis (2nd ed.). Toronto: University of Toronto Press.

Jafari, N. J., Kargozari, M., Ranjbar, R., Rostami, H., Hamedi, H. (2017). The effect of chitosan coating incorporated with ethanolic extract of propolis on the quality of refrigerated chicken fillet. J. Food Process. Preserv., 42(1), e13336.

Jonaidi Jafari, N., Kargozari, M., Ranjbar, R., Rostami, H., Hamedi, H. (2018). The effect of chitosan coating incorporated with ethanolic extract of propolis on the quality of refrigerated chicken fillet. J. Food Process. Pres., 42(1), e13336.

Kabara, J. J. (1991). Phenols and chelators. In N. J. Russell, G.W. Gould (Eds.), Food preservatives (pp. 200-214). London: Blackie.

Kawiji, R. U., Nurhartadi, E., Putra, A. Y. T., Setiawan, A. (2014). The effect of cassava starch-based edible coating enriched with kaempferia rotunda and curcuma xanthorrhiza essential oil on refrigerated patin fillets quality. Int. Food Res. J., 21(1), 413-419.

Kirk, R. S., Sawyer, R. (1991). Pearson's composition and analysis of foods (9th ed.). London: Longman Scientific and Technical.

Munoz, L. A., Cobos, A., Diaz, O., Aguilera, J. M. (2012). Chia seeds: Microstructure, mucilage extraction and hydration. J. Food Eng., 108(1), 216-224.

Nessianpour, E., Khodanazary, A., Hosseini, S. M. (2019). Shelf life of saurida tumbil during storage at refrigeration condition as affected by gelatin-based edible coatings incorporated with propolis extract. Int. J. Food Prop., 22, 1, 1749-1759.

Ojagh, M. S., Rezaei, M., Razaviİ S. H., Hosseini, S. M. H. (2010). Effect of chitosan coatings enriched with cinnamon oil on the quality of refrigerated rainbow trout. Food Chem., 120(1), 193-198.

Ouattara, B., Simard, R. E., Holley, R. A. (1997). Antibacterial activity of selected fatty acids and essential oils against six meat spoilage organisms. Int. J. Food Microbiol., 37, 155-162.
Özyurt, G., Özkütük, A. S., Şimşek, A., Yeşilsu, A. F., Ergüven, M. (2015). Quality and shelf life of cold and frozen rainbow trout (Oncorhynchus mykiss) fillets: effects of fish protein-based biodegradable coatings. Int. J. Food Prop., 18(9), 1876-1887.

Payandan, E., Zayyed-Alangi, S. Z., Shamloofar, M., Koohsari, H. (2017). Study of chemical composition and efficacy of different extracts of iranian propolis on the microbiological and sensory parameters of minced cyprinus carpio meat at $4{ }^{\circ} \mathrm{C}$ storage. J. Aquat. Food Prod. Technol., 26(5), 593-603.

Qiu, X. J., Chen, S. J., Liu, G. M., Yang, Q. M. (2014). Quality enhancement in the japanese sea bass (Lateolabrax japonicas) fillets stored at $4^{\circ} \mathrm{C}$ by chitosan coating incorporated with citric acid or licorice extract. Food Chem., 162, 156-160.

Reis, A. S., Diedrich, C., Moura, C., Pereira, D., de Florio Almeida, C., Silva, L. D., ..., Carpes, S. T. (2017). Physico-chemical characteristics of microencapsulated propolis co-product extract and its effect on storage stability of burger meat during storage at $-15^{\circ} \mathrm{C}$. LWT Food Sci. Technol., 76, 306-313.

Salgado-Cruz, M. P., Calderón-Domínguez, G., Chanona-Pérez, J., Farrera-Rebollo, R. R., Méndez-Méndez, J. V., Díaz-Ramíreza, M. (2013). Chia (Salvia hispanica L.) seed mucilage release characterisation. A microstructural and image analysis study. Ind. Crops Prod., 51, 453-456.

Varlık, C., Ugur, M., Gokoglu, N., Gun, H. (1993). Quality control principles and methods in seafood. Food Technol. J. Publ. 17. İstanbul.

Yazgan, H., Burgut, A., Durmus, M., Kosker, A. R. (2020). The impacts of water and ethanolic extracts of propolis on vacuum packaged sardine fillets inoculated with Morganella psychrotolerans during chilly storage. J. Food Safety, 40(2), e12767.

Zarei, M., Ramezani, Z., Ein-Tavasoly, S., Chadorbaf, M. (2015). Coating effects of orange and pomegranate peel extracts combined with chitosan nanoparticles on the quality of refrigerated silver carp fillets. J. Food Proc. Pres., 39, 2180-2187. 